\title{
Distribution and Abundance of Carangidae (Teleostei, Perciformes) Associated with Oceanographic Factors along the Northeast Brazilian Exclusive Economic Zone
}

\author{
Christiane Sampaio de Souza ${ }^{1,2}$ and Paulo Mafalda Júnior ${ }^{2^{*}}$ \\ ${ }^{l}$ Programa de Pós-graduação em Geologia, Instituto de Geociências; Universidade Federal da Bahia; \\ chsampaio@ig.com.br; Salvador - BA - Brasil. ${ }^{2}$ Laboratório de Plâncton; Instituto de Biologia; Universidade \\ Federalda Bahia; pomafa@ufba.br; 40210-020; Salvador-BA - Brasil
}

\begin{abstract}
This work had as objective to study the distribution and abundance of the Carangidae larvae and to analyze the influence of the hydrological (temperature and salinity) and biological factors (phytoplanktonic biomass and zooplanktonic biomass), on the space and temporal distribution of the larvae. Ichthyoplankton was collected during four expeditions from the Northeast Exclusive Economic Zone. Six species (Trachurus lathami, Decapterus punctatus, Chloroscombrus chrysurus, Selene setapinnis, Selene vomer and Elagatis bipinnulata) and CaranxCarangoides complex were identified. D. punctatus was the species most abundant (52\% of the total), with higher abundance during the Period 3, while the Period 2 was the period of low abundance. C. chrysurus was the second species in abundance representing $30 \%$ of the total of carangid. This species had higher abundance during the Period 2 and the Period 1. However, in Period 3 abundance were lesser. The third species in abundance was T. lathami that corresponded $8 \%$ of the total of carangid larvae. S. setapinnis, S. vomer and E. bipinnulata were the species less abundant, representing together $2 \%$ of the total identified larvae. The larvae of Caranx- Carangoides complex represented $9 \%$ of the carangid total.
\end{abstract}

Key words: Ichthyoplankton, Carangidae, oceanographic factors, Exclusive Economic Zone, Northeast Brazilian coast

\section{INTRODUCTION}

The fishes of the family Carangidae are commonly known as jacks. The carangid fishes inhabit marine and estuarine waters in tropical, subtropical and temperate regions (Bannikov, 1987). They are active swimmers and live in the school or small groups (Berry and Smith-Vaniz, 1978). Many species of the Carangidae are important for the commercial, recreational and aquaculture fisheries
(Katsuragawa and Matsuura, 1992). This family is composed by approximately four subfamilies with 32 genus and 140 species (Nelson, 1994), from which 15 genera occur in the Southeastern Brazil (Menezes and Figueiredo, 1980). In the Northeast Brazilian region 10 adults taxa have been cited: Elagatis, Alectis, Caranx, Carangoides, Oligoplites, Selene, Seriola, Selar, Chloroscombrus, Trachinotus (Lessa et al., 2000; Feitosa et al., 2003; Lima Filho et al. 2006). Very

* Author for correspondence 
little is know about the larval abundance and distribution patterns of the carangid in Brazil with the exception of the distribution and abundance of Chloroscombrus chrysurus larvae along the Southern coast investigated by Weiss et al. (1976). Katsuragawa and Matsuura (1992) described nine taxa in the Southeastern Brazilian. Recent studies about the ichthyofauna of the Northeast Exclusive Economic Zone also present information about the occurrence of Carangidae (Lessa et al., 2000; Feitosa et al., 2003).

The distribution patterns of the fish larvae in any region of the ocean are related to the reproductive activity of the adult population and to the topographic and hydrographic features that affect the dispersal of the larvae (Nonaka et al. 2000). In addition, information can be obtained on the reproductive strategies adopted by these fishes in response to the physical and biological processes of the region (Vorwerk et al., 2003).

Alterations in the physical conditions such as habitat structure would be expected to result in changes in the fish community structure owing to the effect that this change would have on the abundance and composition of the species associated with it. The interactions between the various physical, chemical and biological properties therefore explain why the ecology of marine display changes in time and space (Whitfield and Paterson, 2003). The knowledge of these interactions is important for a better understanding of the interrelationships among fish species during their early life stages, as well as an understanding of adult spawning patterns, recruitment processes and the overall dynamics of fish populations.

The present work analyzed the occurrence of the Carangidae larvae, spatial and temporal distribution patterns of the most abundant species and evaluated the influence of oceanographic factors (temperature, salinity, primary biomass and secondary biomass) on them in the Exclusive Economic Zone of Brazil Northeast.

\section{Study area}

The Exclusive Economic Zone (EEZ) is defined as the area between the external limit of the Territorial Sea, of 12 miles of width and 200 nautical miles of the coast (CNIO, 1998). This study is part of the REVIZEE Program (Assessment of the Sustainable Yield of the Living Resources in the Exclusive Economic Zone). The study area was limited by the estuary of the
Parnaíba River, in the Piauí, and Todos os Santos Bay, in the Bahia, included the Archipelagos of Fernando de Noronha and Saint Peter and Saint Paul. This is tropical oceanic region, constituted of a oligothrophic system, and that it possesses a complex alimentary web, however with low biological productivity (Ekau and Knoppers, 1999). The South Equatorial Current (SEC) reaches the NE Brazilian shelf between 11 and $15^{\circ}$ $\mathrm{S}$. A total of $12 \mathrm{~Sv}$ or more from SEC flows northward to continue as the North Brazil Current (NBC). Only $4 \mathrm{~Sv}$ from the southward flowing Brazil Current (BC) (Peterson and Stramma, 1991).

The SEC comprises a broad westward flow with a mean velocity of 10 to $15 \mathrm{~cm} \cdot \mathrm{s}^{-1}$ and along the equator there is a much swifter current with a mean velocity of $30 \mathrm{~cm} \cdot \mathrm{s}^{-1}$ (Tchernia, 1980). The North Brazil Current follows at a mean velocity of $75 \mathrm{~cm} . \mathrm{s}^{-1}$ with superficial temperature between 28 and $30^{\circ} \mathrm{C}$, and superficial salinity between 35.0 and 37.0 psu (Medeiros et al., 1999). The Brazil Current flows at a mean velocity of 10 to $15 \mathrm{~cm} . \mathrm{s}^{-1}$ with mean superficial temperature of $26^{\circ} \mathrm{C}$ and salinity above of $35 \mathrm{psu}$ (Tchernia, 1980).

\section{MATERIALS AND METHODS}

A total of 562 samples were collected during four expeditions realized between 1995 and 2000 (Fig. $1)$. The expeditions were made during August to October of 1995 (Period 1), January to April of 1997 (Period 2), April to July of 1998 (Period 3) and September to December of 2000 (Period 4).

The ichthyoplankton samples were collected by Bongo nets with $50 \mathrm{~cm}$ of mouth diameter, 500 and $300 \mu \mathrm{m}$ meshes, but only larvae collected with $500 \mu \mathrm{m}$ net were considered in this study. The nets were equipped with two independent flowmeters to estimate the water volume filtered.

The sampling method used followed Smith and Richardson (1977). The sampling was done through oblique hauls from the maximum depth of $200 \mathrm{~m}$ to the surface. The duration of the tow was 10 minutes. The samples obtained were preserved in $4 \%$ buffered formalin - seawater. In the laboratory, all the Carangidae larvae were removed from each sample and stored in $70 \%$ alcohol.

The carangidae larvae were identified to the lowest possible taxonomic level according to the morphological characters of each group 
(Katsuragawa, 1990). Standard densities of the individual taxa were expressed as the number per

$100 \mathrm{~m}^{3}$ of filtered water for each collection.

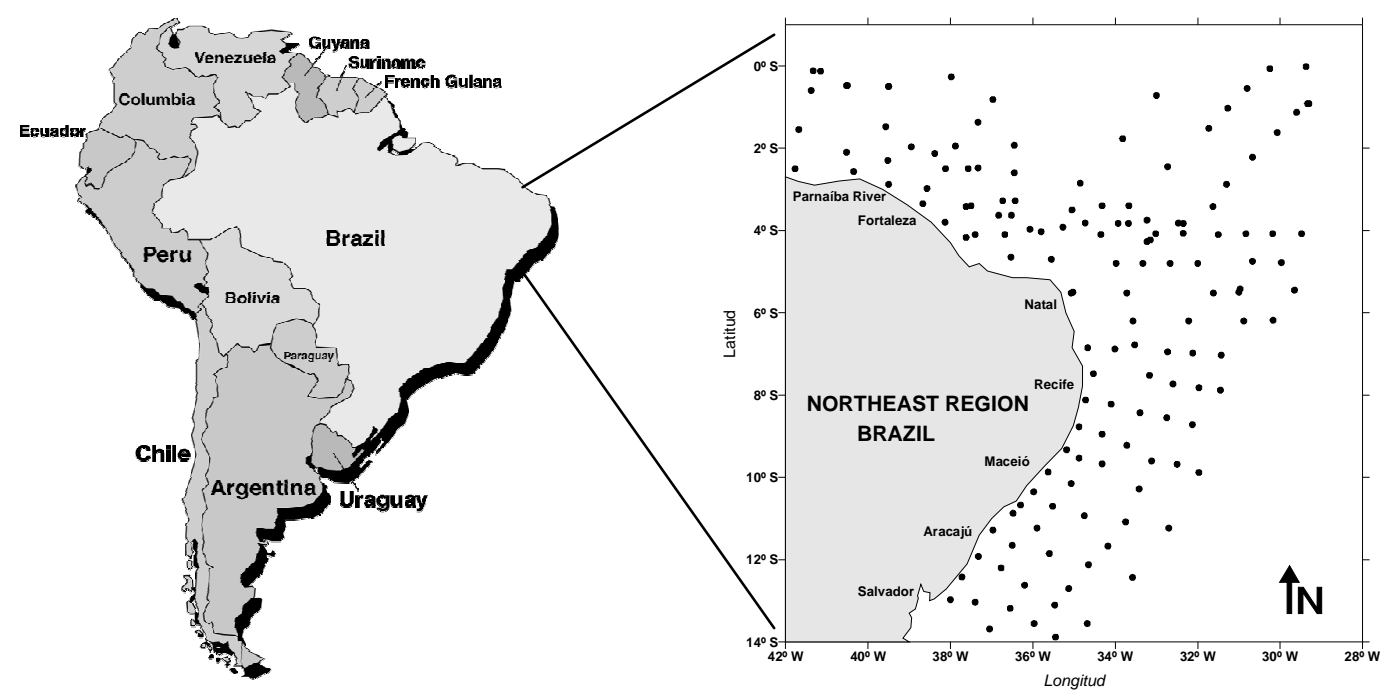

Figure 1- Study area showing the sampling stations.

Temperature and salinity were record by ctd.

The water samples for the determination of the phytoplanktonic biomass (chlorophyll $\boldsymbol{a}$ ) in $1 \%$ of light were obtained using the fluorescence method. The determination of the secondary biomass (dry weight) was carried through according to methodology of Omori and Ikeda (1984).

\section{Data analysis}

In order to determine the statistical significance of the temporal variables on biotic and abiotic factors, were used non-parametric Kruscal-Wallis and test of multiple comparisons of Dunn. The canonical correspondence analysis (CCA), a unimodal for non-linear multivariate gradient analysis (Ter Braak, 1986), was employed for this study using the CANOCO program. The Canonical Correspondence Analysis (CCA) used the environmental information to constrain a reciprocal averaging ordination between the taxa and respective sample. The canonical correspondence analysis was used to study the relationships between the abundance of the family Carangidae and oceanographic variables (temperature, salinity, primary biomass and secondary biomass).

\section{RESULTS}

\section{Hydrographic condition}

The water temperature ranged between 26.1 and $27.8^{\circ} \mathrm{C}$ (mean $=26.6^{\circ} \mathrm{C}$ ) to the surface during the period 1 , between 26.2 and $29.4^{\circ} \mathrm{C}$ (mean $=28.9^{\circ}$ C) during the period 2 , between 25.8 and $28.6^{\circ} \mathrm{C}$ (mean $=27.1^{\circ} \mathrm{C}$ ) during the period 3 and between 25.7 and $28.4^{\circ} \mathrm{C}\left(\right.$ mean $\left.=26.8^{\circ} \mathrm{C}\right)$, during the period 4 (Fig. 2). In the temperature variations up to $1.5^{\circ} \mathrm{C}$ between periods 1 and 2 was observed. 


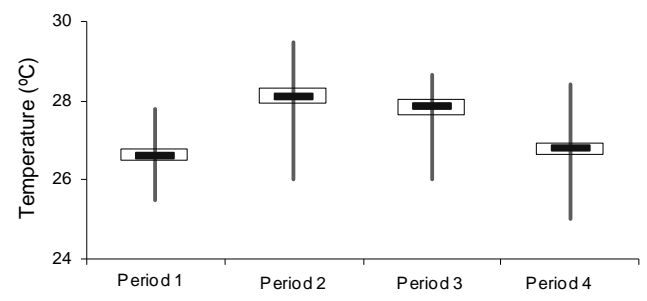

Figure 2 - Temporal variation of temperature for investigated periods (minimum and maximum values: vertical line; mean: horizontal bar; confidence limit: rectangle).

There were significant differences in the temperature between the four analyzed periods (Kruskal-Wallis, $\mathrm{p}<0.0001$ ). The test of multiple comparisons of Dunn showed that the periods 1 and 4 differed from the periods 2 and 3.

Salinity ranger from 35.5 to 37.3 (mean $=36.1$ ) during the period 1, between 34.8 and 37.2 (mean $=36.2$ ) during the period 2, between 34.5 and 37.4 $($ mean $=36.4)$ during the period 3 and between 35.2 and $37.2($ mean $=36.3)$, during period 4 (Fig. $3)$.

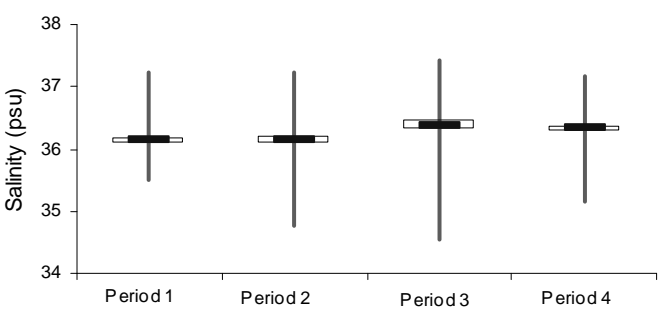

Figure 3 - Temporal variation of salinity for investigated periods (minimum and maximum values: vertical line; mean: horizontal bar; confidence limit: rectangle).

The salinity was significantly different among the periods (Kruskal-Wallis, $\mathrm{p}<0.0001$ ). The test of the multiple comparisons of Dunn showed that the periods 1 and 2 differed from the periods 3 and 4 . The values of salinity and temperature registered in all the periods, indicated the presence of the Superficial Equatorial Water, which had a salinity $>35$ and temperature $>26^{\circ} \mathrm{C}$, and Coastal Water, with salinity around 35 (Fig. 4).
PERIOD 1

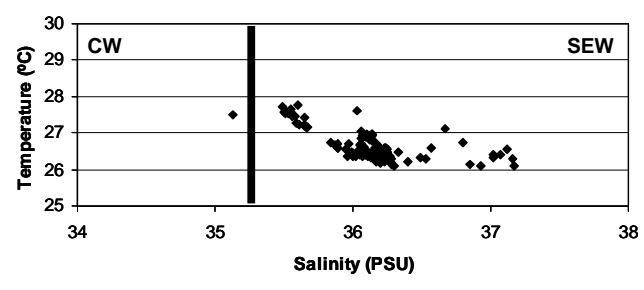

PERIOD 3

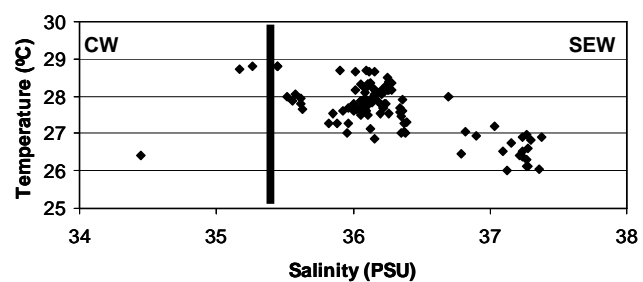

PERIOD 2
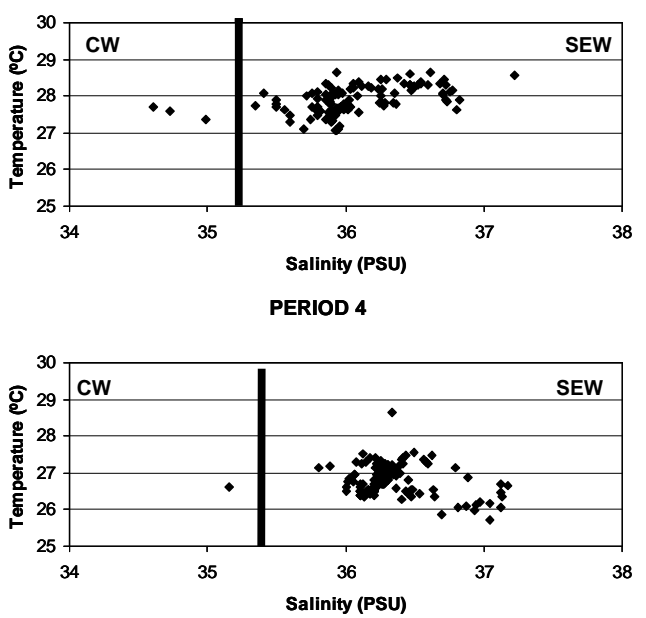

Figure 4 - T-S Diagram for investigated periods. 


\section{Primary Biomass}

The lowest primary biomass was found in the period 1 with values between 0.03 and $0.2 \mu \mathrm{g} . \mathrm{L}^{-1}$. Intermediate values varying between 0.2 and 3.9 $\mu \mathrm{g} . \mathrm{L}^{-1}$ were observed in the period 2 . The highest values was observed in the periods 3 and 4 , it oscillated between 0.1 and $5.1 \mu \mathrm{g} . \mathrm{L}^{-1}$, and between 0.2 and $5.9 \mu \mathrm{g} . \mathrm{L}^{-1}$, respectively (Fig. 5). The primary biomass was significantly different among periods (Kruskal-Wallis, $\mathrm{p}<0.0001$ ).

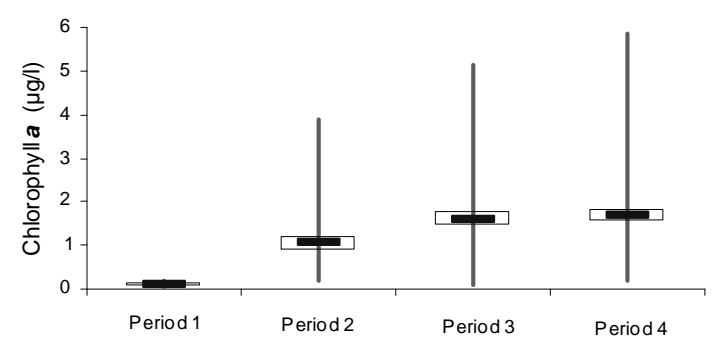

Figure 5 - Temporal variation of chlorophyll $a$ for investigated periods (minimum and maximum values: vertical line; mean: horizontal bar; confidence limit: rectangle).

\section{Secondary Biomass}

The dry weight presented lower values during Period 1 oscillating between 0.02 and 1.6 g. $100 \mathrm{~m}^{-3}$ and during Period 4, oscillating between 0.2 and $2.4 \mathrm{~g} .100 \mathrm{~m}^{-3}$. Intermediate values varying between 0.07 and $4.1 \mathrm{~g} .100 \mathrm{~m}^{-3}$ were found in the Period 3 .
The highest values were found in the Period 2 (0.03 to 11.3 g. $100 \mathrm{~m}^{-3}$ ) (Fig. 6). The secondary biomass was significantly different among the periods (Kruskal-Wallis, $\mathrm{p}<0.0001$ ).

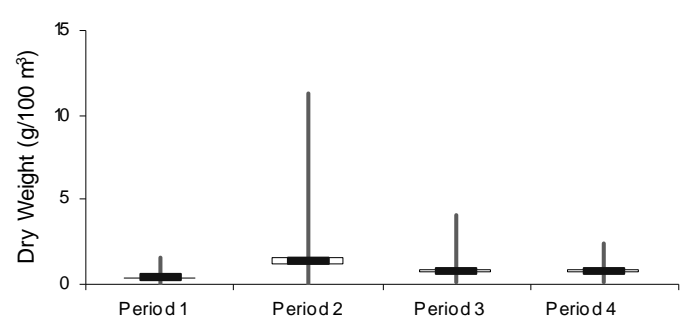

Figure 6 - Temporal variation of dry weight for investigated periods (minimum and maximum values: vertical line; mean: horizontal bar; confidence limit: rectangle).

Carangidae larvae occurrence and composition A total of 313 larvae representing six species (Trachurus lathami, Decapterus punctatus, Chloroscombrus chrysurus, Selene setapinnis, Selene vomer and Elagatis bipinnulata) and two genera (Caranx and Carangoides) were identified in the EEZ Northeast. D. punctatus, C.oscombrus chrysurus and Trachurus lathami were the most dominant species comprising $89.1 \%$ of the larvae composition.

D. punctatus was the most abundance species $(51.8 \%)$. The higher abundance were observed during periods 1 and 3, while period 2 was lower abundance. C. chrysurus was the second species in abundance, representing $29.7 \%$. The higher abundance occurred during period 2. T. lathami represented $7.7 \%$ of total Carangidae larvae and was more abundance during period 4. Selene setapinnis, Selene vomer and Elagatis bipinnulata were less abundant, contributing $2.2 \%$ of total larvae. The members of Caranx and Carangoides complex comprised less than 9\% of the total (Fig. 7).

\section{Spatial and temporal distribution of species}

The carangidae larvae were collected more frequently within the neritic zone of the Northeast Brazil. 


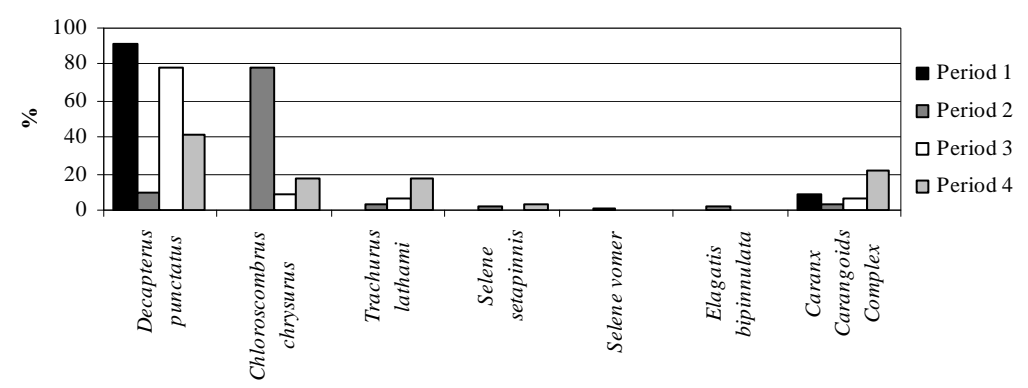

Figure 7 - Relative abundance of species for investigated periods.

D. punctatus presented large distribution occurring in the neritic and oceanic region. D. punctatus larvae were collected in all the periods with the maximum density during period 3 in the area between Parnaíba and Salvador (Fig. 8).C. chrysurus larvae were found predominantly in the neritic stations. The highest density occurred near the Parnaíba river mouth, during the period 2. This species did not occur during period 1 (Fig. 8). T. lathami occurred mainly in the neritic stations, between Natal and Aracaju, during the period 3 and in the Fernando de Noronha Archipelago during the period 4 (Fig. 8).
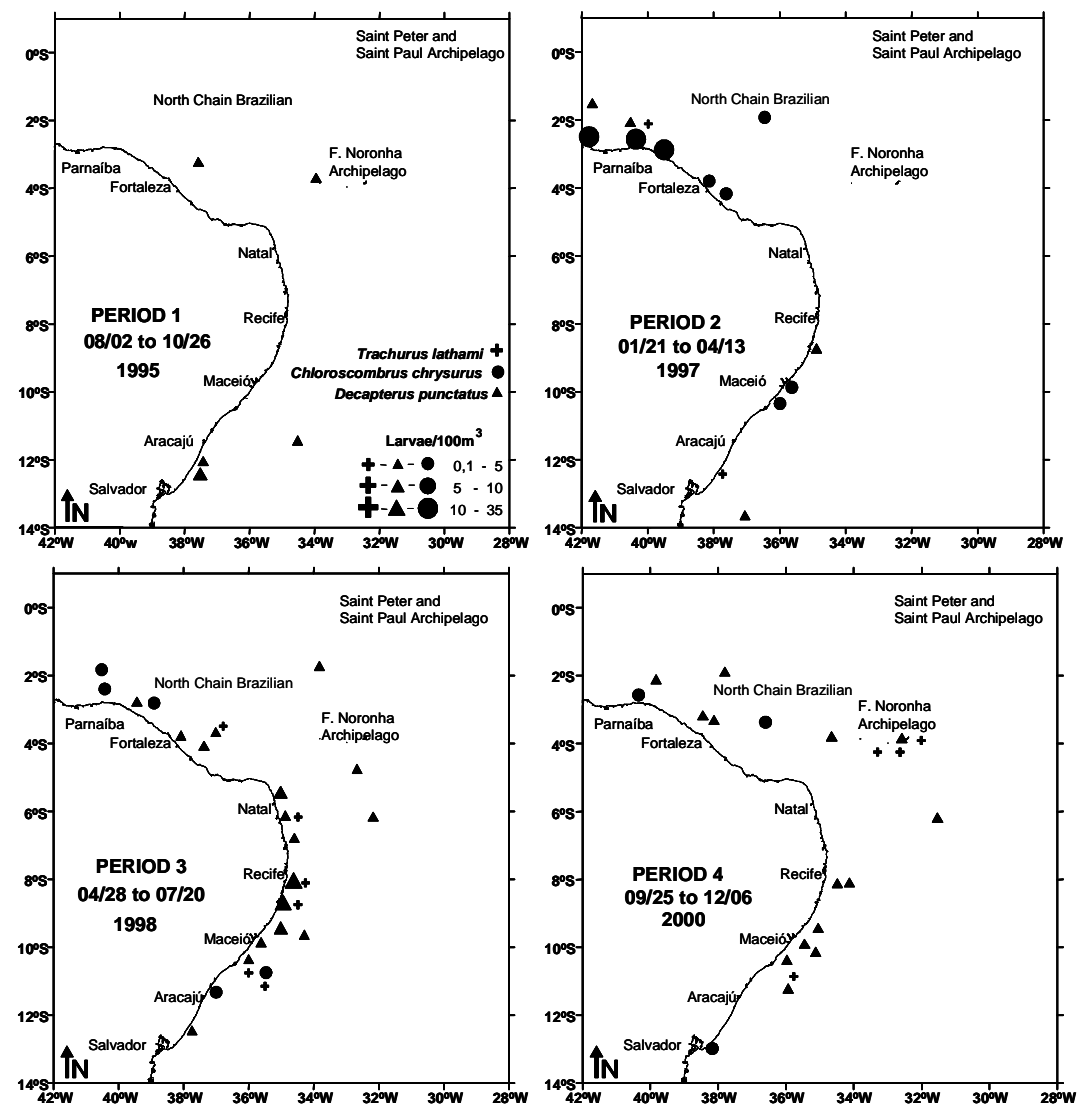

Figure 8 - Temporal and spatial distribution of Decapterus punctatus, Chloroscombrus chrysurus and Trachurus lathami (larvae. $100 \mathrm{~m}^{-3}$ ), in the Northeast ZEE. 


\section{Correlations between Carangidae larvae and oceanographic factors}

The higher Decapterus punctatus densities were found in a wide temperature range between $26.1^{\circ}$ $\mathrm{C}$ and $28.9^{\circ} \mathrm{C}$. The salinity of all positive stations varied from 36.7 to 37.3 , the primary biomass varied from 0.69 to $2.70 \mu \mathrm{g} . \mathrm{L}^{-1}$ and secondary biomass 0.28 to $0.90 \mathrm{~g} .100 \mathrm{~m}^{-3}$.

Temperature variation in positive stations of Chloroscombrus chrysurus was between 28.4 and $29.2^{\circ}$ C. Salinity variation was between 36.5 and 37.2.

Secondary and primary biomass variation was between 0.2 and $1.4 \mu \mathrm{g} . \mathrm{L}^{-1}$ and between 0.5 and $2.3 \mathrm{~g} .100 \mathrm{~m}^{-3}$, respectively.

The highest Trachurus lathami densities occurred in the temperature between 25.4 to $26.8^{\circ} \mathrm{C}$.

The salinity variation was between 34.99 and 36.36. T. lathami larvae were found in the secondary and primary biomass range between 0.95 and $1.4 \mu \mathrm{g} . \mathrm{L}^{-1}$ and between 0.31 and 1.2 g. $100 \mathrm{~m}^{-3}$, respectively.

Eigenvalues, measures of the importance for the CCA axes that can vary between zero and one, ranged from 0.022 for CCA 2 to 0.701 for CCA 3 (Table 1).

Table 1 - Results from Canonical Correspondence Analysis.

\begin{tabular}{lccccc}
\hline & \multicolumn{3}{c}{ CCA axes } & \multicolumn{1}{c}{ Total inertia } \\
\cline { 2 - 5 } & $\mathbf{1}$ & $\mathbf{2}$ & $\mathbf{3}$ & $\mathbf{4}$ & 1.472 \\
\hline Eigenvalues & 0.233 & 0.022 & 0.701 & 0.516 & \\
Species-environment correlations & 0.501 & 0.202 & 0.108 & 0.095 \\
Cumulative percentage variance & & & & & \\
$\quad$ of species data & 15.8 & 17.3 & 64.9 & 100.0 \\
$\quad$ of species-environment relation & 63.4 & 89.5 & 98.3 & 100 & 1.472 \\
Sum of all eigenvalues & & & & & 0.255 \\
Sum of all canonical eigenvalues & & & &
\end{tabular}

The first two CCA axes explained $89.5 \%$ of the cumulative percentage variance of the speciesenvironmental. The Monte Carlo test was significant for the first CCA axes $(\mathrm{p}=0.012)$ and all CCA axes $(p=0.016)$. The low multiple regression coefficients of the environmental variables indicated that there was no collinear variables. This was important because multicollinear variables might be deleted from the analysis.

The plot of CCA sample and species scores illustrates their dispersion pattern and the plot of the oceanographic variables vectors illustrat the directions and strengths of the environmental relationships within the first two dimensions of the CCA ordination (Fig. 9).

The dispersion of CCA sample and species scores resulted from the linear combinations of the oceanography variables. Strong environmental gradients were important correlates with the abundance of Carangidae family in the CCA. The temperature water, primary biomass and secondary biomass correlated particularly well with the CCA axes 1 , and the salinity correlated well with the CCA axes 2 (Fig. 9). These environmental gradients also reflected the spatial and temporal changes in the density species.

C. chrysurus was positively correlated with first CCA axes. D. punctatus was negatively correlated with the first and second CCA axes and T. lathami was positively correlated with the second CCA axes. This implied that $C$. chrysurus (Chl) occurred mostly at high water temperature and secondary biomass during the period 2. D. punctatus (Dec) appeared preferentially during the period 3 at high salinity and primary biomass, whereas $T$. lathami (Tra) predominantly occurred at low salinity during the period 4 (Fig. 9). 


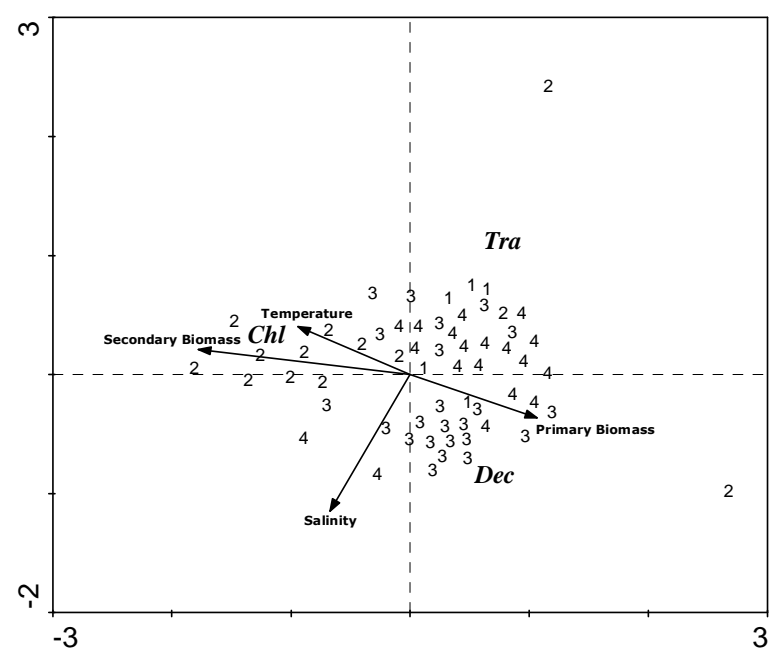

Figure 9 - Ordination diagram of the Canonical Correspondence Analysis (CCA) (1: Period 1; 2: Period 2; 3: Period 3; 4: Period 4).

\section{DISCUSSION}

According to the temperature and salinity results, the study area presented typical characteristics of the tropical regions, with high salinity and temperature, low thermal oscillation and oligothrophic water. The oceanic regions within tropical zones are usually considered oligothrophic owing to minimal vertical flow of the nutrients and subsequent low biological productivity (Longhurst and Pauly, 1987). Such characteristics may be explained by the existence of a warm surface layer above a colder and denser subsurface layer, which creates a permanent thermocline.

This tends to inhibit the upward flow of the nutrient of rich deeper layers, restricting the primary production in surface waters (Travassos et al., 1999).

While the majority of the tropical regions are characterized by the minimal vertical circulation, in some areas, the mixing is promoted via localized mechanisms such as the divergence of the currents, wind stress tension and interaction between the oceanic currents and submarine relief (Roden, 1987; Petit et al., 1989; Rogers, 1994). In the Atlantic Ocean off the North - East Brazil, there are three areas where submarine relief and local current may facilitate the hydrographic process. These include the Saint Peter and Saint Paul Archipelago, Fernando de Noronha Chain and North Brazilian Chain (Travassos et al., 1999).
An important source of the nutrients in the superficial oceanic areas is the vertical transport of the deep water, rich in nutrients (Eppley, 1979). However in the areas where the upwelling was not observed, the recycling processes and regeneration of the superficial organic matter became an important source of the nutrients (Taniguchi, 1972). The nutrients, primary production and plankton are submitted to the temporal variability, in the waters near the coast to Pernambuco (Eskinazi-Leça and Koening, 1986; Gomes, 1991; Passavante and Feitosa, 1995;). The variation in the hydrographic structure seems to have an important influence on the spawning season and area as well as on the distribution pattern and abundance of the fishes larvae (Sabatés et al. 2001).

They were also abundant in other areas of the western Atlantic. Flores-Coto et al. (2001) observed that among eight species of the carangid larvae collected in the southern Gulf of Mexico the three most abundant species were $C$. chrysurus (54.2\%) D. punctatus $(15.8 \%)$ and T. lathami (11.8\%).

Low abundance of other genera and species of the carangids in this study coincided with the results obtained in the southern Gulf of Mexico by other authors (Aprieto, 1974, Ditty et al., 2004).

It was found that the Carangidae species spawned primarily within the neritic zone of the Northeast Brazil, but utilized different spawning strategies to 
reduce the co-occurrence of the larvae. Several species spawn offshore, but their larvae return to nursery grounds located in the shallow, inshore waters. This reproductive style appeared to maximize the probability of the survival through the planktonic phase and has been well documented for some species of the coastal fishes in the tropics, including the Carangidae (VásquezYeomans, 2000). The period of occurrence of some groups was restricted to the Period 2, like the cases of $E$. bipinnulata and $S$. vomer. $E$. bipinnulata spawning in the oceanic waters (Aprieto, 1974) and adults were common offshore (Nakamura, 1980).

The cases where the occurrence was during all the year, was observed the existence of a preferential period; Period 4 for Caranx-Carangoides complex, Period 3 and Period 4 for T. lathami and $D$. punctatus, and Period 2 for $C$. chrysurus. This study showed that the Carangidae fish presented similar reproductive strategies, spawning at a favourable period for each species. It is known that most of the species have characteristic reproductive strategies, adjusting their reproductive patterns with the environmental factors, such as the surface current. For example, in the northeast Pacific, many coastal species which have pelagic stages of the larvae, tend to spawn during the winter, when wind - induced surface transport directs onshore and not during the intensive upwelling season when there is a strong offshore transport (Katsuragawa and Matsuura, 1992).

Favourable larval habitats have been defined by both their biological (e.g. high abundance of food, low abundance of predators) and physical (e.g. circulation patterns promoting retention or transport to nursery area) characteristics (Heath, 1992). However, the environmental conditions at the time of egg and larval development may differ from year to year, due to variation in the environmental characteristics, changes in the timing of emergence of eggs and larvae or a combination of both (Page and Frank, 1989).

T. lathami larvae had the most densities in less saline waters in comparision to the D. punctatus and $C$. chrysurus. Larvae of $C$. chrysurus occurred in higher temperature comparing with $D$. punctatus and T. lathami. There was spatial and temporal variation in the distribution and abundance, and possibly in the reproductive cycle of the Carangidae species. Ditty et al. (2004) found the larvae of several species of the carangids
(C. chrysurus, T. lathami, D. punctatus, C. crysos, $O$. saurus and $H$. amblyrhynchus) in hydrographically dynamic areas.

Variation in the oceanographic environmental on the annual scale may cause interannual changes in both the distributional range of the adults fishes and the features of their spawning environment such as the timing, duration and location of the spawning (Doyle et al., 1993). Thus, studies have examined the larval distributions within a dynamic framework as simple hydrographic correlations have not explained the significant amounts of the variability in the distribution of the assemblages or in the recruitment process (Govoni, 1993; Cowen et al., 1993; Dempster et al., 1999). The meteorological and oceanographic conditions influence the availability of the food organisms and the eggs and larval transport by the residual current and thus affect the reproductive success, resulting in the recruitment variation (Norcross and Shaw, 1984).

Examining the spatial and temporal patterns in the distribution and abundance of the ichthyoplankton in relation to the oceanographic conditions may provide insight into the adaptation of the spawning strategies to the prevailing physical and biological processes as well as into the effect of the variability in these processes on year - class strength (Somarakis et al., 2002). Among the causes that influence the distribution of the ichthyoplankton is the trophic relations of the spawning adult populations and the transport of the ichthyoplankton by chains (Arosemena et al., 2000), while the initial phases study of the fish life cycle permit an adequate and more profitable use of fishery resources (Lasker, 1987).

In conclusion, the results this study demonstrated that the studied oceanographic factors (temperature, salinity, primary biomass and secondary biomass) appeared to influence the abundance of the Carangidae species, allowing that each species had a period and place more favourable to spawn in the Brazil Northeast Exclusive Economic Zone.

\section{ACKNOWLEDGEMENTS}

The authors express their thank to the Ministry of Environment, Direction of Hydrography and Navigation and ANTARES oceanographical ship for supporting this study though the program REVIZEE. 


\section{RESUMO}

Este trabalho teve como objetivo estudar a distribuição e abundância das larvas de Carangidae, foi analisada também a influência de fatores hidrológicos (temperatura e salinidade) e biológicos (biomassa fitoplanctônica e biomassa zooplanctônica), sobre a distribuição espacial e temporal dessas larvas. $\mathrm{O}$ ictioplâncton foi coletado durante quatro expedições: Período 1 (Agosto - Outubro 1995), Período 2 (Janeiro Abril 1997), Período 3 (Abril - Julho 1998) e Período 4 (Setembro - Dezembro 2000)), realizadas na Zona Econômica Exclusiva do nordeste. Em um total de 313 larvas foram identificadas 6 espécies (Trachurus lathami, Decapterus punctatus, Chloroscombrus chrysurus, Selene setapinnis, Selene vomer e Elagatis bipinnulata) e o Complexo Caranx - Carangoides pertencentes à família Carangidae. D. punctatus foi a espécie mais abundante neste estudo (52\% do total). Sua maior abundância foi observada no Período 3 e a menor no Período 2. C. chrysurus foi a segunda espécie em abundância representando $30 \%$ do total de carangídeos. Esta espécie teve maior abundância durante o Período 2, enquanto que os Períodos 1 e 3 foram ás épocas de menor abundância. A terceira espécie em abundância foi T. lathami que correspondeu $8 \%$ do total de larvas de carangídeos, sendo o Período 4 o mais abundante. S. setapinnis, S. vomer e E. bipinnulata foram bem menos abundantes que as outras espécies analisadas, representando juntas $2 \%$ do total de larvas identificadas. Larvas do Complexo Caranx - Carangoides representaram 9\% do total de carangídeos.

\section{REFERENCES}

Aprieto V. L. (1974), Early development of five carangid fishes of the Gulf of Mexico and the South Atlantic Coast of the United States. Fish Bull., 72, 414-443.

Arosemena, D.; Olivera B. E. and Ulates S. (2000), Ictioplâncton em la Zona Portuária de Limón, Costa Rica. Bull. Inst. Smithsonian de Investigaciones Tropicales, Ancón, 24, 436-452.

Bannikov, A. F. (1987), On the taxonomy, composition and origin of the Family Carangidae. J. Icht., 27, 1-8.
Berry, F. H.; Smith-Vaniz W. F., 1978. Carangidae. In: W. FISHES ed. 1978. FAO species identification sheets for fisheries purposes. Western Central Atlantic. Fishing area 31. Rome, FAO, v.1.

Boltovskoy, D. (1981), Atlas del Zooplancton del Atlántico Sudoccidental y métodos de trabajo con el zooplancton marino, ed. INIDEP, Mar del Plata: INIDEP, pp 936.

Cowen, R. K.; Hare, J. A. and Fahay, M. P. (1993), Beyond hydrography. Can physical processes explain larval fish assemblage within the middle Atlantic bight? Bull. Mar. Sci., 53, 567-587.

(CNIO) Comissão Nacional Independente sobre os Oceanos. (1998). Os usos dos oceanos no século XXI: A Contribuição Brasileira. Relatório final à comissão mundial independente sobre os oceanos.

Dempster, T.; Gibbs, M. T.; Rissik, K. D. and Suthers, I. M. (1999), Beyond hydrograph: daily ichthyoplankton variability and short term oceanographic events on the Sydney Continental Shelf. Cont. Shelf Res., 41, 563-571.

Ditty J. G.; Shaw R. F.; Cope J. S. (2004), Distribution of carangid larvae (Teleostei: Carangidae) and concentrations of zooplankton in the northern Gulf of Mexico, with illustrations of early Hemicaranx amblyrhynchus and Caranx spp. Larvae. Mar. Biol., 145, 1001-1014.

Doyle, M. J.; Morse, W. W. E. and Kendall Jr., A. W. (1993), A comparision of larval fish assemblages in the temperate zone of northeast Pacific and the northwest Atlantic ocean. Bull. Mar. Sci., 53, 588644.

Eppley, R. W. and Weiler, C. S. (1979), The dominance of nanoplankton as an indicator of marine pollution: a critique. Ocea. Acta, 2, 24, 1-245.

Ekau, W; Westhaus-Ekau, P. and Medeiros, C. (1999), Large scale distribution of fish larvae in the continental shelf waters off North-East Brazil. Arch. of Fish. and Mar. Res. 47, 183-200.

Ekau, W. and Knoppers, B. (1999), An introduction to the pelagic system of the north-east and east Brazilian shelf. Arch. of Fish. and Mar. Res, 47, 113-132.

Eskinazi-Leça, E. And Koening, M. L. (1986), Diatoms (Bacillariophyceae) distribution in the Suape area (Pernambuco-Brazil). Trab. Ocea. Univ. Fed. PE., 19, 73-100.

Feitosa, M. B.; Rocha, A. L.; Luiz-Junior, J. O.; Floeter, R. S. and Gasparini, L. J. (2003), Reef fishes of st Paul's rocks: new record and notes on biology and zoogeography. Jour. of icht. and aqua. Biol., 7, 6182.

Flores-Coto C.; Rivas-Vega R.; Zavala-Garcia F.; Sanchez-Robles J. (2001), Vertical distribution of larval carangids in the southern Gulf of Mexico. Gulf Carib Res., 13, 1-8. 
Gomes, N. A. (1991), Estrutura e composição florística do fitoplâncton na plataforma continental norte de Pernambuco (Brasil). Paper presented at $4^{\text {th }}$ Encontro Brasileiro do Plâncton, Recife, UFPE, 35-53.

Govoni, J. J. (1993), Flux of larval fishes across frontal boundaries: Examples from the Mississippi river plume front and the western gulf stream front in winter. Bull. of Mar. Sci., 53, 538-566.

Heath, M. R. (1992), Field investigations of the early life stages of marine fish. Adv. Mar. Biol., 28, 174.

Katsuragawa, M. (1990), Estudo sobre o desenvolvimento, a distribuição e a abundância de larvas de carangídeos da costa sudeste do Brasil. $\mathrm{PhD}$ thesis, São Paulo University, São Paulo, Brazil.

Katsuragawa, M. and Matsuura, Y. (1992), Distribution and abundance of carangid larvae in the southeastern Brazilian bight during 1975-1981. Bolm. Inst. Ocea. 40: (1/2). 55-78.

Lasker, R. (1987), Use of fish eggs and Larvae in probing some major problems in fisheries and aquacuture. National Marine Fisheries Service. Paper presented at American Fisheries Society Symposium, USA, 2, $1-16$.

Lessa, R.; Nóbrega, F. M. Santana, F. M.; Souto, G. S.; Balensifer, P.; Duque, P.; Charles, W. D. (2000), Guia de identificação de peixes marinhos da região nordeste. DIMAR, In Programa REVIZEE / ScoreNE, pp.138.

Lima Filho, J. M.; Lessa R.; Stosic B.; Duarte Neto P. J. and Vieira J. W. (2006), Morphological Discrimination in Juveniles of Two Selene Species (Teleostei: Carangidae) Using Truss Net Distances. Brazilian Archives of Biology and Technology, 49: (2), 231-238.

Longhurst, A. R. and Pauly, D. (1987), Ecology of tropical Oceans. New York: Academic Press, Inc. pp.407.

Medeiros, C.; Macedo, S. J.; Feitosa, F. A. N. and Koening, M. L. (1999), Hydrography and phytoplankton biomass and abundance of North-East Brazilian Waters. Arch. of Fish. and Mar. Res., 47: (2/3), 133-151.

Menezes, N. A. and Figueiredo, J. L. (1980), Manual de peixes marinhos do sudeste do Brasil - IV. Teleostei (3). São Paulo, Museu de Zoologia da Universidade de São Paulo, pp.96.

Nakamura E .L. (1980), Carangids of the northern Gulf of Mexico. In: Flandorfer M, Skupien L (eds) Proceedings of a workshop for potential fishery resources of the northern Gulf of Mexico, March 4-5, 1980, New Orleans, La., pp 18-33.

Nelson, J. S. (1994), Fishes of world. New York, Jonh Wiley e Sons.

Neumann-Leitão, S.; Gusmão, L. M.; Silva, T.; Nascimento-Vieira, D. A. and Silva, A. P. (1999), Mesozooplâncton biomass and diversity in coastal and oceanic waters off North-Eastern Brazil. Arch. of Fish. and Mar. Res., 47: (2/3), 153-165.
Nonaka R. H.; Matsuura Y.; Suzuki K. (2000), Seasonal variation in larval fi sh assemblages in relation to oceanographic conditions in the Abrolhos Bank region off eastern Brazil. Fish. Bull., 98, 767-784.

Norcross, B. L. and Shaw, R. F. (1984), Oceanic and estuarine transport of fish eggs and larvae: a review. Trans. Amer. Fish. Sco., 113, 153-165.

Omori, M. and Ikeda, T. (1984), Methods in marine zooplankton ecology. John wiley e Sons, New York.

Page, E. H. and Frank, K. T. (1989). Spawning time and eggs stage duration in Northwest Atlantic haddock (Melanogrammus aeglefinus) stocks with emphasis on Georges and Browns Bank. J. Fish. Aquat. Sci., 46, 68-81.

Passavante, J. Z. O. and Feitosa, F. A. N. (1995), Produção primária do fitoplâncton da plataforma continental de Pernambuco (Brasil): área de Piedade. Bol. Téc. Cient. CEPENE, 3, 7-22.

Petit, M. ; Strtta, J. M. ; Simier, M. and Wadswrth, A. (1989), Anomalies de surface et pêche thonière: SPOT et la dètection de zones de pêche par l' inventarie des hauts-fonds. Mappe Monde 3, 13-19.

Peterson, R. G. and Stramma, L. (1991), Upper-level circulation in the South Atlantic Ocean. Progress in Oceanography, 26, 1-75.

Roden, G. I. (1987), Effect of seamounts and seamount chains on acean circulation and thermohaline structure. In: Keating, B. H., Fryer P., Batiza R., Boehlert G. W. (eds): seamounts, islands and atolls. AGU, Geophys. Monogr. 43, 335-354.

Rogers, A. D. (1994), the biology of seamounts. Adv. Mar. Biol. 30, 305-350.

Sabatés, A.; Salat, J.; Olivar M. P. (2001), Advection of continental water as an export mechanism for anchovy, Engraulis encrasicolus, larvae. Sci. Mar., 65, 77-87.

Smith, P. E. and Richardson, S. L. (1977), Standart techniques for pelagic fish eggs and larvae surveys. FAO Fish. Tech. Pap., 175, 1-100.

Somarakis, S.; Drakopoulos, P. and Filippou, V. (2002), Distribution and abundance of larval fish in the northern Aegean Sea - eastern Mediterranean - in relation to early summer oceanographic conditions. $J$. of Plank. Res., 24, 339-357.

Taniguchi, A. (1972), Geographical variation of primary production in the western Pacific Ocean and adjacent seas with reference to the interrelation between various parameters of primary production. Mem. Fac. Fish. 19, 1-34.

Tchernia, P. (1980), Descriptive regional oceanography. Oxford: Pergamon Press. 253pp.

Ter Braak, C. J. F. (1986), Canonical correspondence analysis: A new eigenvetor technique for multivariate direet gradient analysis. Ecology, 67, 1167-1179.

Travassos, P.; Hazin, F. H. V.; Zagaglia, J. R.; Advíncula, R. and Schober, J. (1999), Thermohaline structure around seamounts and islands off North- 
Eastern Brazil. Arch. of Fish. and Mar. Res., 47: (2/3), 211-222.

Vásquez-Yeomans, L. (2000), Seasonal variation of ichthyoplankton in a western Caribbean bay system. Envi. Biol. of Fish., 58, 379-392.

Vorwerk, P. D.; Whitfield, A. K.; Cowley, P. D. and Paterson, A. W. (2003), The influence of selected environmental variables on fish assemblage structure in a range of southeast African estuaries. Envir. Biol. of Fish., 66, 237-247.

Weiss, G.; Souza F. J. A. and Santos, A. (1976), Contribuição ao conhecimento do ictioplâncton marinho da costa sul do Brasil. Atlântica, 42, 79-99.
Whitfield, A. K. and Paterson, A. W. (2003), Distribution patterns of fishes in a freshwater deprived Eastern Cape estuary, with particular emphasis on the geographical headwater region. Water SA, 29, 61-67.
Received: April 13, 2006; Revised: July 26, 2007; Accepted: March 27, 2008. 